\title{
ハシブトガラスの行動圈特性の把握と 個体数調整対策のための計画圈域の検討
}

\author{
Determining Characteristics of Jungle Crow's Home-range \\ and a Planning Area for Developing a Policy to Control Crows Population
}

\author{
藤田 紀之* 服部 俊宏** 東 淳樹*** 尾上 舞**** 矢澤 正人**** 瀬川 典久****** \\ Noriyuki FUJITA*, Toshihiro HATTORI**, Astuki AZUMA***, Mai ONOUE****, \\ Masato YAZAWA*****, Norihisa SEGAWA****** \\ $(*$ 明治大学大学院農学研究科 **明治大学農学部 $* * *$ 岩手大学農学部 $* * * *$ 元岩手大学大学院農学研究科 \\ *****数理設計研究所 $* * * * * *$ 岩手県立大学ソフトウェア情報学部) \\ (*Graduate school of Agriculture, Meiji University **School of Agriculture, Meiji University ***Faculty of Agriculture, Iwate University \\ ****Ex-Graduate school of Agriculture, wate University *****Mathematical Assist Design Laboratory \\ ******Faculty of Softeare and Information Science, Iwate Prefectual University)
}

\section{I はじめに}

ハシブトガラス Corvus macrorhynchos（以下，カラス） の生息分布域は，人間の生活圏と重複している場合が多 く，有害鳥となる場合が多い。例えば，様々な農作物に 対して被害を出しており（犬飼·芳賀 ${ }^{1)}$, 農林水産省 ${ }^{2)}$ ), 被害の低減が求められている。また都市域においては, 生ゴミの食い荒らし問題などが起きており（松田 ${ }^{3)}$, 日 本野鳥の会 $\left.{ }^{4)}\right)$, 街の美観を損なうため解決が望まれて いる。これらを解決するためには，生息地管理等による 長期的な個体数調整が必要であると指摘されている（百 瀬ら $\left.{ }^{5)}\right)$ 。しかし, 現在行なわれている個体数調整対策は, 主に捕獲小屋を用いたカラスの駆除であり，この方法で 捕獲される個体は経験の浅い若鳥が多い (玉田・深松 $\left.{ }^{6)}\right)$ 。 これは，越冬できずに死亡する可能性が高い個体を捕獲 していることになり, 地域の個体数レベルを下げること につながりにくいことが指摘されている $\left(\right.$ 吉田 $\left.^{7)}\right)$ 。

ある地域の獣害を低減するためには，地域内の餌場価 值を低下させ，野生動物に対する「餌付け」を行わない ことが重要であると指摘されている $\left(\right.$ 井上 $\left.{ }^{8}\right)$ 。このよ うな考え方は，カラスの個体数調整対策に対しても有効 であると考えられる。つまり，地域レベルで個体数調整 対策を行うということは, 地域内で「カラスに食べさせ ない環境づくり」を推進していくことであると考えられ る。しかし，個体数調整対策の計画圈域の大きさについ て具体的に検討した事例はなく，またどのような環境条 件の場所に対し重点的に対策をとれば良いかについて， あまり議論されてこなかった。そこで, 本研究では, カ
ラスの行動圈の大きさや形状の特徵から, 計画圈域につ いて検討する。さらにカラスがよく利用する領域内の環 境の特徴から, どのような環境を選択的に利用していた かを明らかにし，重点的に対策が必要となる環境につい て検討する。

\section{II 研究方法}

\section{1 調査地および調査対象}

調査は, 岩手県内陸部中央に位置する盛岡市西部と隣 接する市町で行なった。調査地の面積は約 $470 \mathrm{~km}^{2}$, 標 高は約 $80 \sim 370 \mathrm{~m}$ で, 調査地中心部の標高が比較的低 く, 周囲の標高が高くなっており, すり鉢状の地形をし ている。また調查地中央部は農村的な環境と都市的な環 境が混在しており，周囲は森林に囲まれている。さらに 宅地及び農耕地と森林の境界部には果樹園が多く存在 する。盛岡駅の北東約 $2.5 \mathrm{~km}$ にハシブトガラスとハシ ボソガラスの混合ねぐらがあり，盛岡市の調べによる と，ねぐらを利用している個体数は 1990 年以降 4000 5000 羽で安定している $\left(\right.$ 東 $\left.^{9}\right)$ 。本研究では, このねぐ らを主に利用するカラスを対象にした。

\section{2 捕獲と追跡方法}

2011 年 12 月， 2012 年 $9,11 ， 12$ 月， 2013 年 7,8 月 に，あらかじめ盛岡市から捕獲許可を得て，有害駆除用 の捕獲罠を使ってカラスを捕獲した。7，8月に行なっ た捕獲では, 十分な大きさのカラスを確保できない可能 性があったため，捕獲罠 1 および 2 で捕獲した（図 1)。 
それ以外の時季の調査では, 捕獲罠 1 で捕獲した（図 1)。 捕獲したカラスのうち，2011 年は 6 個体， 2012 年の

9,11 月は 8 個体, 12 月は 3 個体, 2013 年は 4 個体 に対し，観測間隔を $15 ， 30 ， 72$ 分間隔に設定した GPSTX を装着し，捕獲罠付近で放鳥した。放鳥した全個体 の口内はピンク色だったため，玉田 ${ }^{10)} に$ に倣い，放鳥し た全てのカラスは生後 1 年以内の幼鳥とした。GPS-TX は鳥類や哺乳類の行動調査を目的に開発された, GPS 受信機, 制御装置, 無線通信機を組み合わせた機器であ り，GPS-TXを使うことで追跡対象動物の位置情報の自 動取得とリアルタイム追跡が可能となる (矢澤ら $\left.{ }^{11)}\right)$ 。 GPS-TX は装着総重量が $30.5 \mathrm{~g}$ であるため, 体重が $610 \mathrm{~g}$ 以上のカラスに装着した。GPS-TXを使ってカラスの位 置情報を自動的に収集し，さらにカラスの行動を観察す るため, 夏季のカラス 2 個体 (ID57 および ID58) に対し, ID57 は 2013 年 7 月 23 日〜 2013 年 7 月 27 日, ID58 は 2013 年 7 月 23 日〜 2013 年 7 月 25 日に, 日出 1 時間後 から日没時間ごろまでの間 (おおよそ 5:30〜 19:00) で, 動きのあった個体を追跡した。

\section{3 解析方法}

（1）解析に使用したカラスの位置情報

季節による特徵の違いを把握するため, 7,8 月を夏
季, 9,11 月を秋季, 12,1 月を冬季として解析を行な った。また放鳥直後のカラスはあまり動きを見せなかっ たので，放鳥翌日からの位置情報を使って解析を行なっ た。さらに, 本研究では, 日中の利用環境を対象として いるため, 収集した位置情報のうち, 観測日の夜明けか ら日没までの位置情報のみで解析を行なった。夜明け時 間，日没時間は国立天文台が公開している情報（http:// eco.mtk.nao.ac.jp/cgi-bin/koyomi/koyomix.cgiを参照) に基づいて決定した。観測間隔と行動圈の面積, 及びデ ー夕取得日数と面積との間に関係性が見受けられなかっ たため（表 1), 本研究では全ての観測デー夕を用いて 解析を行なった。

（2）行動圈の推定方法

計画圈域を検討するため, 95\%最外郭法を使ってカラ スの行動圈を推定した。最外郭法はこれまでに最もよく 使われてきた方法であり, 手法が簡単な上に直感的に理 解しやすいという利点を持つものの, 未利用地を多く含 むといった問題点が指摘されている（尾崎ら $\left.{ }^{12)}\right)$ 。計画 圈域を検討する場合，未利用地が含まれていてもできる だけ広く推定した行動圈から検討した方が適切だと考 え, 最外郭法を用いた。また, 行動圈の形状を特徵づけ るため, 行動圈の方位角と行動圈の面積を算出した。方 位角は, 行動圈ポリゴンの長軸と北のなす角とした。方

表 1 観測データの基本情報と, 行動圈及び集中利用域の面積

Table 1 Basic information of the observation data and area of home-range and core area

\begin{tabular}{|c|c|c|c|c|c|c|}
\hline 季節 & ID & 観測間隔(分) & データ取得日数(日) & 行動圈の面積 (ha) & 集中利用域の面積 (ha) & 行動圈の方位角 ( $\left.{ }^{\circ}\right)$ \\
\hline \multirow{5}{*}{ summer } & 57 & 15 & 5 & 12 & 6.62 & 24 \\
\hline & 58 & 15 & 3 & 587 & 61.89 & 1 \\
\hline & 60 & 30 & 6 & 74 & 9.91 & 79 \\
\hline & 61 & 30 & 7 & 3 & 1.32 & 74 \\
\hline & 平均 & & & 169 & 19.94 & \\
\hline \multirow{9}{*}{ autumn } & 43 & 15 & 6 & 172 & 27.17 & 161 \\
\hline & 44 & 15 & 8 & 254 & 51.57 & 76 \\
\hline & 45 & 30 & 10 & 43 & 17.74 & 9 \\
\hline & 47 & 72 & 10 & 865 & 24.19 & 147 \\
\hline & 48 & 72 & 8 & 2851 & 57.96 & 109 \\
\hline & 49 & 15 & 6 & 1544 & 91.08 & 158 \\
\hline & 50 & 30 & 14 & 1861 & 311.87 & 162 \\
\hline & 51 & 72 & 26 & 199 & 114.34 & 168 \\
\hline & 平均 & & & 974 & 86.99 & \\
\hline \multirow{10}{*}{ w inter } & 33 & 15 & 7 & 713 & 40.11 & 161 \\
\hline & 34 & 15 & 5 & 470 & 41.02 & 129 \\
\hline & 35 & 15 & 6 & 713 & 40.11 & 161 \\
\hline & 39 & 15 & 6 & 1930 & 209.69 & 108 \\
\hline & 40 & 15 & 4 & 239 & 40.49 & 152 \\
\hline & 42 & 15 & 8 & 3299 & 714.41 & 167 \\
\hline & 52 & 72 & 11 & 112 & 10.35 & 153 \\
\hline & 53 & 72 & 21 & 168 & 22.15 & 4 \\
\hline & 54 & 30 & 6 & 1201 & 62.84 & 155 \\
\hline & 平均 & & & 983 & 131.24 & \\
\hline
\end{tabular}


位角の算出には(株オープン GIS が公開しているプログ ラム（http://www.opengis.co.jp/htm/basic/draw_axes. htm を参照）を用いた。さらに，カラスがよく利用す る領域（集中利用域）を推定するため, 最小クロスバリ デーションを用いた固定カーネル法を使用し，利用分 布の $95 \%$ を含む領域を推定した。行動圈と集中利用域 の推定, 方位角の算出には GIS ソフトウェア TNTmips v2012（MicroImages 社）を用いた。

（3）選択的に利用していた領域内の環境解析

カラスが選択的に利用した環境を明らかにするため, 各個体の集中利用域内の土地利用割合を集計した。また, 季節ごとにカラスが選択的に利用した環境に違いがある かを明らかにするため, 各個体の土地利用割合を季節ご とに平均した。土地利用は環境省がインターネット上で 公開している「環境省第 $6 \cdot 7$ 回自然環境保全基礎調査 植生調査」の成果を基に作成した。具体的には，公開さ れている 2 万 5 千分の 1 の植生図（鷹高, 姥屋敷, 小岩 井農場, 盛岡, 南昌山, 区界, 矢幅) を使用し, 凡例を 統合した。なお，凡例の統合については，藤田ら ${ }^{13)} に$ 倣った。行動圈と集中利用域内の土地利用の集計には, GIS ソフトウェア TNTmips v2012 を使った。

III 結果

\section{1 カラスの行動圏}

図 1 に示すように, 夏季のカラスの行動圈は, ねぐら から $5.7 \mathrm{~km}$ の範囲内にあった。また行動圈の形状は 4 個体中 2 個体が小さな楕円形で, 細長い楕円形, 三角形
に似た形状だったのがそれぞれ 1 個体いた（表 1)。ま た行動圈面積は 3 ha 587 ha であり, 夏季のカラスの行 動圈の面積には個体差があった。最も行動圈面積の大き かった個体の行動圈は, 北-南方向, 次いで行動圈面積 の大きかった個体の行動圈は, 東一西方向に広がってい た（表 1)。

秋季のカラスの行動圈は, ねぐらから $10.1 \mathrm{~km}$ の範囲 内にあった（図 1)。ほとんどの行動圈の形状は細長く 楕円に近い形だった。追跡した 8 個体中 4 個体の行動圈 が北－南方向に広がり, 次いで東－西方向の行動圈を持 つ個体が多かった（表 1)。行動圈面積は 43 ha 〜 2851 ha となり, 夏季と同じように行動圈面積には個体差が あった。夏季の行動圈面積と比較すると, 平均面積が 4 倍以上大きく, 秋季の方が広い行動圈を持つという特徵 があった。

冬季のカラスの行動圈は, ねぐらから $14.0 \mathrm{~km}$ の範囲 内に収まっていた（図 1)。全ての行動圈の形状は細長 く楕円に近い形だった。追跡した 9 個体中 4 個体の行動 圈は北－南，さらに 4 個体が北西－南東方向に広がって いた(表 1)。また行動圈面積は 112 ha〜 3299 ha であり， 最も広い行動圈を持っていた。

\section{2 集中利用域の分布と土地利用}

夏季における集中利用域内の土地利用は, 緑の多い住 宅地（公園的な樹林, 植え込み, 農地等の緑被がおおむ ね 30\%以上で住宅地等と混在する領域）が $25.5 \pm 8.6 \%$ (平均值 標準誤差), 樹林が $22.3 \pm 11.5 \%$, 果樹園が $20.5 \pm 15.2 \%$ の順に高かった（図 2 ）。また集中利用

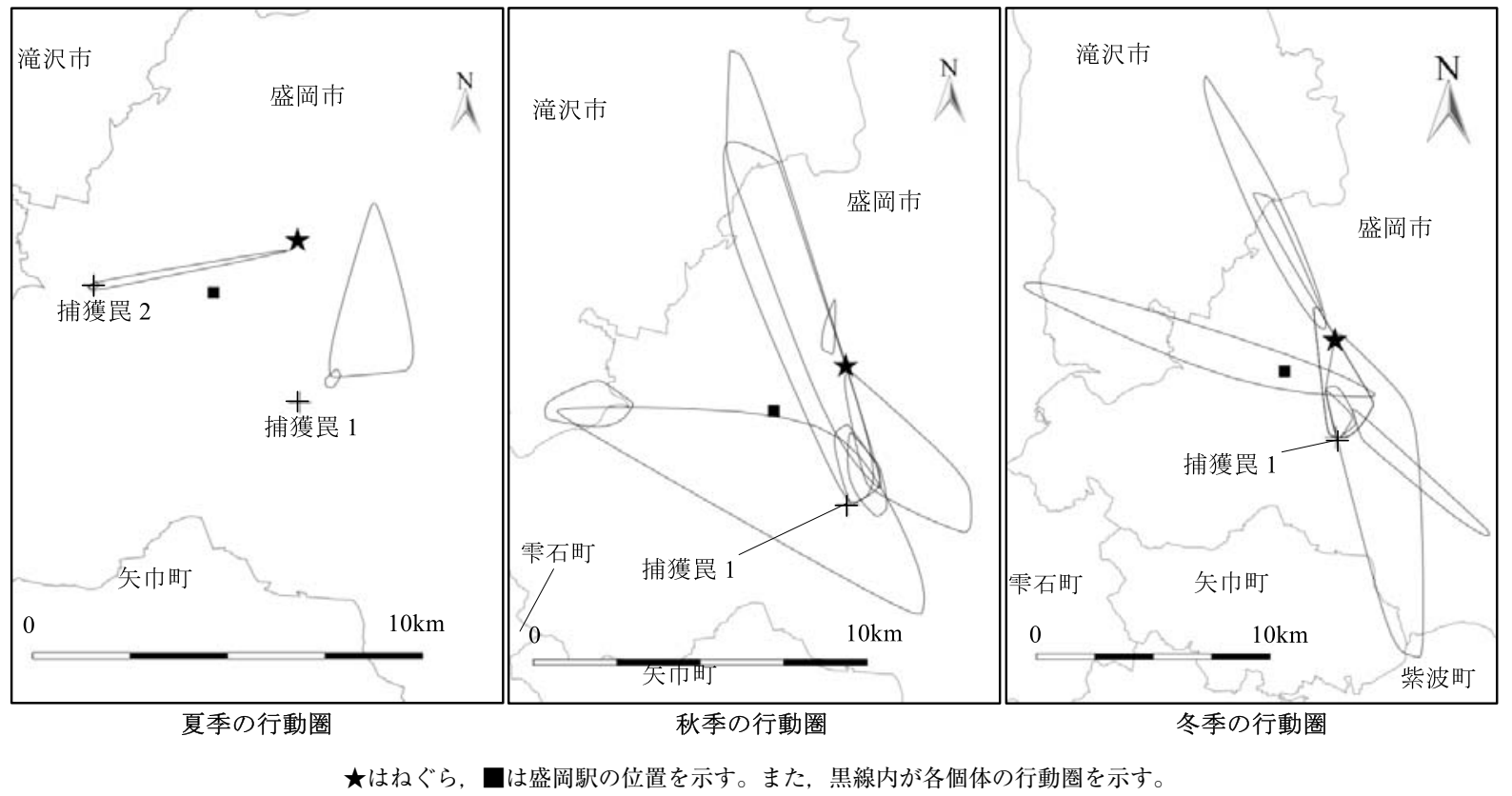

図 1 各季節のカラスの行動圈

Fig. 1 Home range of Jungle crow at each seasons 
域の分布は, 市街地, 連続した樹林（以下，森林）およ び果樹園が近接している領域で重なり合っているという 特徴があった（図 3)。

秋季における集中利用域内の土地利用割合は，果樹園 が $28.4 \pm 8.0 \%$, 市街地（緑被率が $30 \%$ 未満で, 住宅地, ビル, 道路, 人工構造物が卓越する領域）が $24.5 \pm 5.3 \%$, 樹林が $12.9 \pm 3.1 \%$ だった（図 2 ）。また集中利用域の分 布は, 市街地, 森林および果樹園が近接している領域で 重なり合っていた（図 4）。夏季と比較すると，集中利 用域が広く分布していた。

冬季における集中利用域内の土地利用割合は，市街地 が $29.6 \pm 6.1 \%$ ，果樹園が $17.2 \pm 3.7 \%$ ，樹林が $16.0 \pm$ $3.0 \%$, 草地・牧草地が $15.7 \pm 4.4 \%$ だった（図 2 ）。ま た集中利用域の分布は，市街地，森林および果樹園が近 接している領域で重なり合っていた（図 5)。また夏季, 秋季よりも，集中利用域が広く分布する傾向があった。

\section{3 夏季のカラスの行動}

個体 ID57 は, 7 月 23 日 10 時 50 分頃まで図 1 に示し た捕獲罠 1 から半径 $184 \mathrm{~m}$ 以内に滞在した後, 12 時 20 分頃に果樹園へ移動し，16 時頃まで滞在していた。そ の後 16 時頃に果樹園と樹林の境界部へ移動し，それ以 降あまり動かなかった。 7 月 24 日は, 4 時 30 分頃に果 樹園に隣接した緑の多い住宅地へ移動し, 緑の多い住宅
地とその周辺半径 $136 \mathrm{~m}$ 以内に滞在していたが, 9 時頃 に果樹園へ戻り，その後は 1 日中果樹園に滞在していた が, 18 時 20 分頃に果樹園と樹林の境界部へ移動し, そ れ以降あまり動かなかった。この境界部は 7 月 23 日に 利用していた場所と同じ場所だった。 7 月 25 日は, 5 時 30 分に果樹園へ移動し, その後果樹園内に滞在してい た。16時頃に

7 月 23 日， 7 月 24 日に利用していた境界部へ移動し, その後はあまり動かなかった。 7 月 26 日は 5 時 30 分頃 に果樹園へ移動し，1 日中果樹園に滞在し，17 時頃に前 日までと同じ境界部へ移動した。移動後はあまり動かな かった。

他方, 個体 ID58 は, 7 月 23 日 7 時 30 分頃まで捕獲 罠 1 から半径 $430 \mathrm{~m}$ 以内に滞在していたが， 8 時頃に果 樹園へ移動し，9 時頃まで果樹園と周辺の半径 $687 \mathrm{~m}$ の 範囲内に滞在していた。その後, 転々と移動していた が, 13 時頃に樹林へ移動し, 以降樹林に滞在しており, この日は侍へ向かわなかった。 7 月 24 日は, 5 時頃に樹 林に囲まれた畑へ移動し, 8 時 15 分頃まで半径 $126 \mathrm{~m}$ 以内へ滞在していた。その後, 15 時 30 分頃に草地（ゴ ルフ場）へ移動した後, 17 時 30 分頃まで滞在し, 18 時 15 分頃にねぐらへ向かった。 7 月 25 日は 5 時頃にねぐ らから移動を開始し, 5 時 30 分頃樹林に隣接した緑の 多い住宅地へ移動し，10 時頃に樹林に囲まれている畑

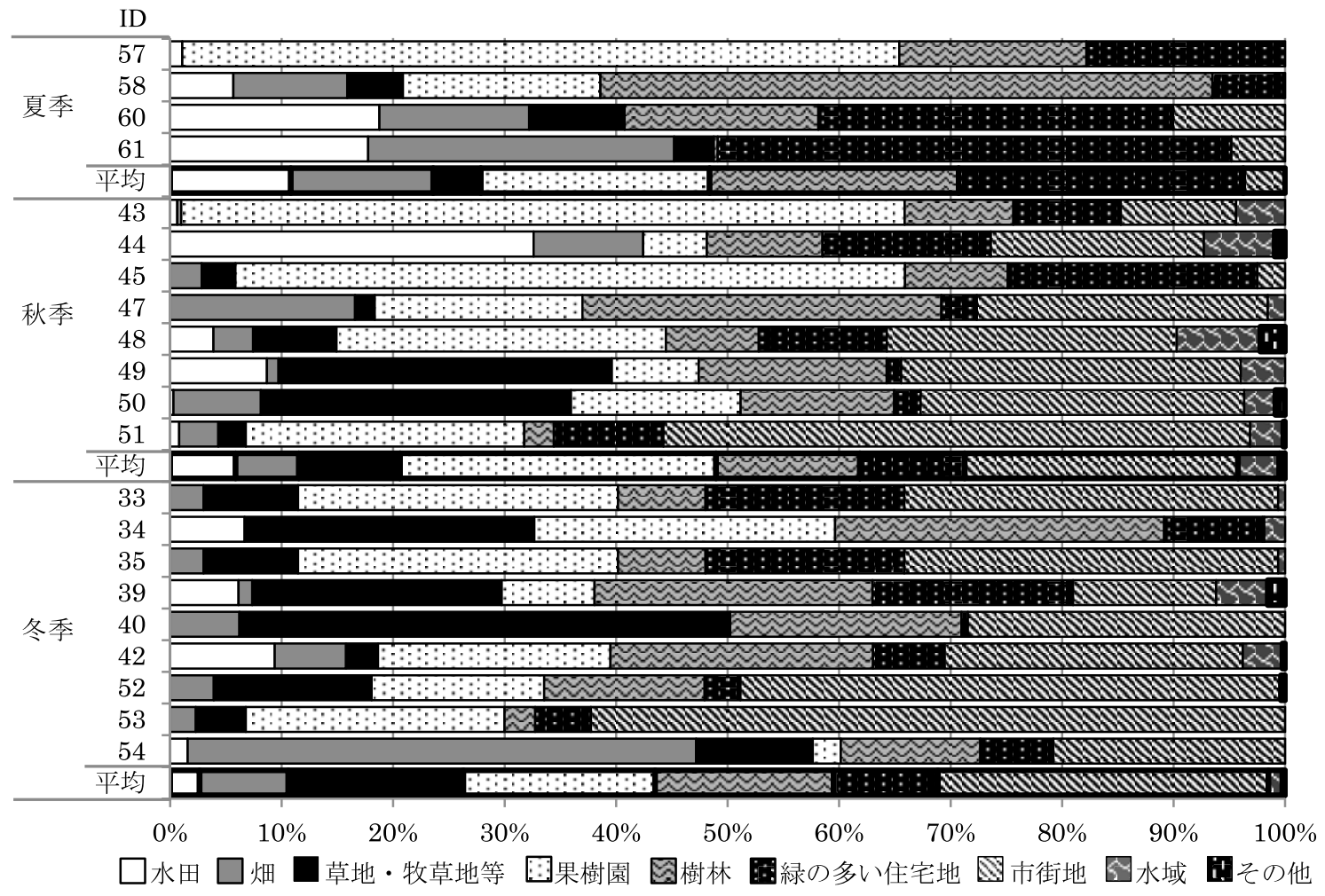

図 2 集中利用域内の土地利用割合

Fig. 2 Percentage of landuse in core area 


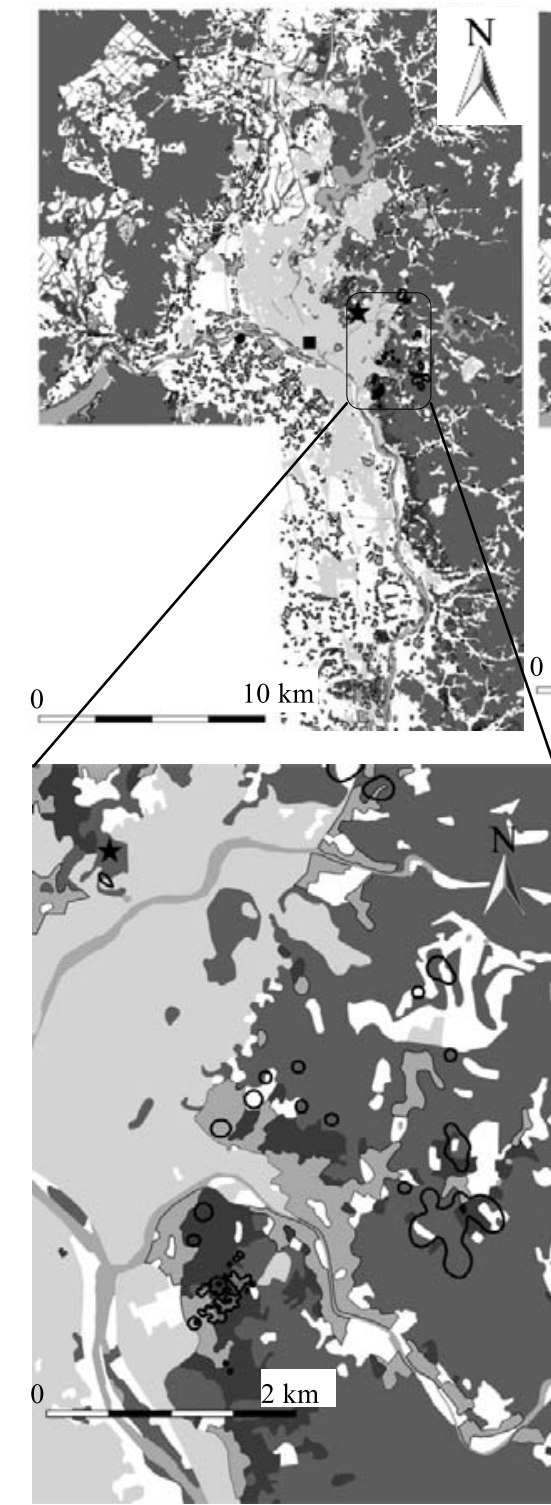

図 3 夏季の集中利用域の分布

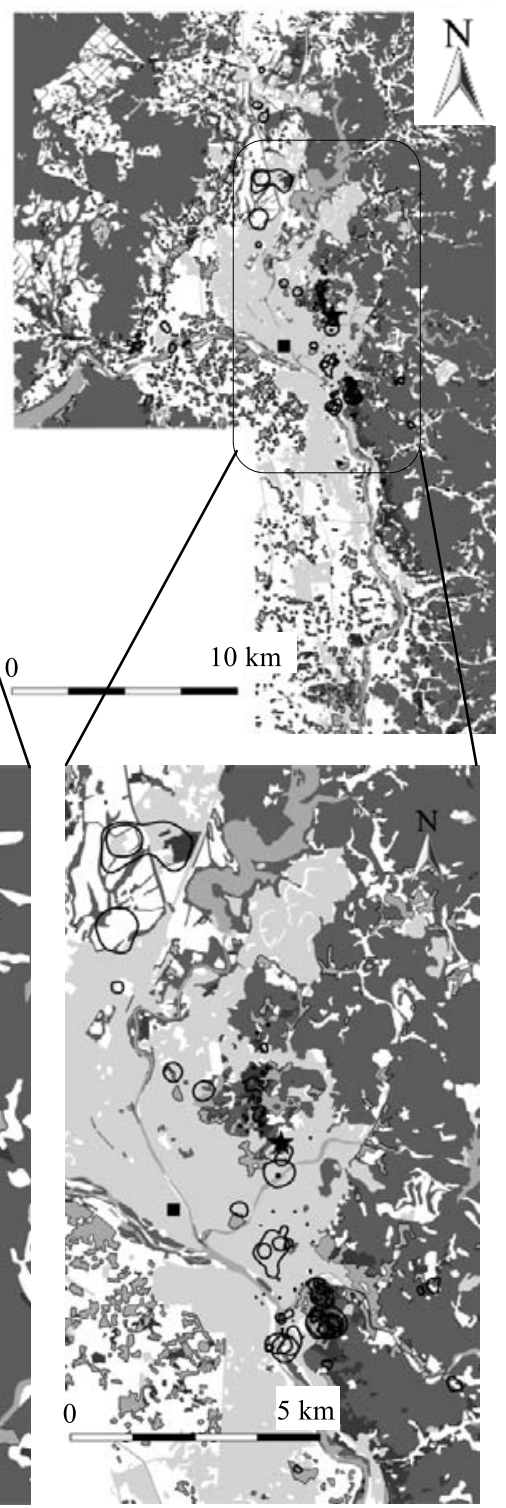

図 4 秋季の集中利用域の分布

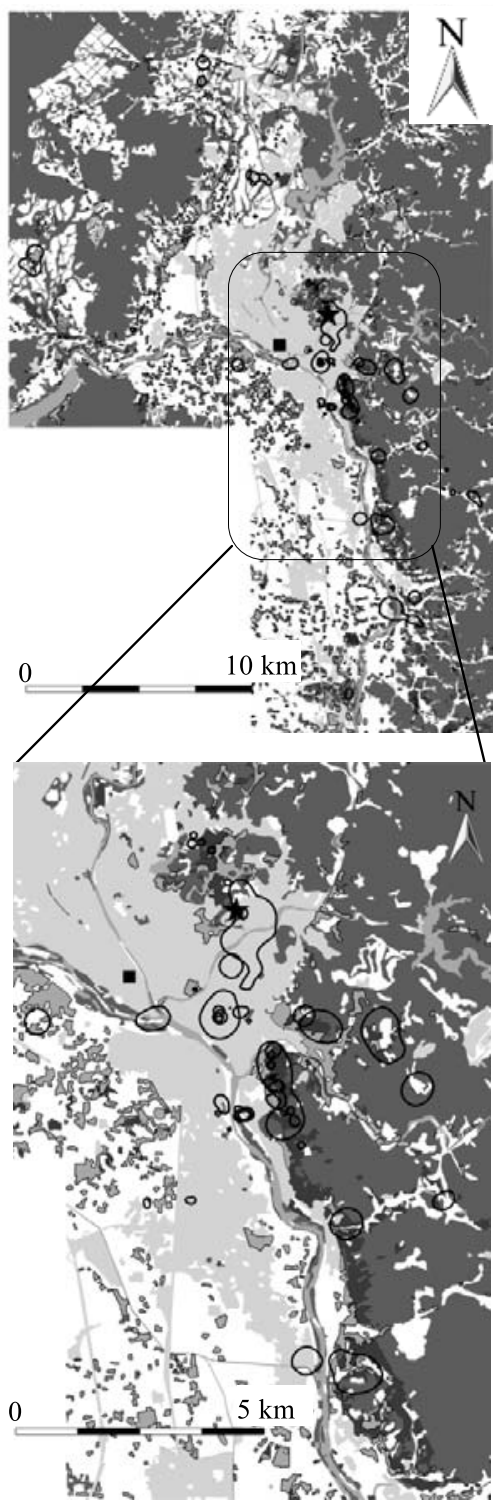

図 5 冬季の集中利用域の分布

Fig. 3 Distribution of core area at summer Fig. 4 Distribution of core area at autumn Fig. 5 Distribution of core area at winter

凡例

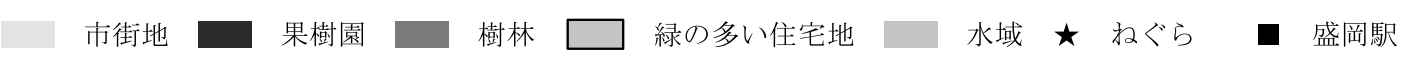
太線内が集中利用域を示す

と市街地が隣接した場所へ移動し, その場所で 1 日を過 ごしていた。

夏季のカラスを追跡した結果，果樹園において地面を つついているところを観察した。追跡していたカラスが 飛び立った後, つついていた場所を探ったところ, 刈ら れた下草がそのままになっており，そこにはコオロギや コガネムシ, バッ夕類などの昆虫類がいた。また果樹園 内には摘果したリンゴも多くあったが，このようなリン ゴには見向きもせず, 前年の廃棄されたと思われるリン ゴを採慨していた。

\section{IV 考察}

\section{1 行動圏}

秋・冬季の行動圈は, 北-南方向に広がる傾向があっ た（表 1 および図 1$)$ 。本調査地のカラスは, 餌場とし て畜（鷄）舎や果樹園を利用していることが明らかにな っている $\left(\right.$ 東ら $\left.{ }^{14)}\right)$ 。ねぐらの北側にはいくつかの畜(鵎) 舎が点在し, 南側には果樹園が広く存在する。秋・冬季 のカラスは, これら両方の環境を利用していたため, 行 動圈は南北方向に広がったと考えられる。 
各季節の行動圈の面積を比較すると, 夏季よりも秋季, 秋季よりも冬季の方が広かった（表 1 )。また，ねぐら からの距離にも同様の傾向があり, 季節を追うごとにカ ラスの行動圈は広がることが明らかになった。

図 3，4，5から，どの季節もよく利用されている果樹 園に加えて, 秋・冬季には十分なエサ資源を確保するた めに, ねぐらの南側方向に連続して存在する果樹園や北 側に点在する畜（鵎）舎など，より広域でエサ資源を探 索していることが考えられた。

\section{2 選択的に利用する環境}

夏季の集中利用域内の土地利用は, 緑の多い住宅地, 樹林, 果樹園の順で高く（図 2), 集中利用域はこれら の土地利用が近接する領域だった（図 3)。集中利用域 内の果樹園では, 主にリンゴが栽培されていたことから, 夏季のカラスは樹木の多い環境を選択的に利用していた と言える。カラスは夏季に樹木の実をよく食べることか ら (大飼ら $\left.{ }^{1)}\right)$, 樹木の多い環境は, エサ資源を獲得で きる環境として重要であると考えられる。また，枝葉が 遮蔽物となるため, カラスが身を隠す環境としての役割 もあると考えられる。以上から，「樹木の多い」ことが 環境選択の条件として重要であると考えられる。また, 人の生活の場から離れた森林内部には集中利用域があま りないことから（図 3), 夏季のカラスは, 人の生活の 場が隣接する樹木が多い環境をよく利用していたと考え られる。

秋季の土地利用は果樹園, 市街地, 樹林の順に割合が 高かった（図 2）。秋季の集中利用域の分布から（図 4), 集中利用域が夏季よりも広く分布する傾向があることが 明らかになった。夏季と秋季における集中利用域の分布 と土地利用を比較すると, 夏季と同じ果樹園をよく利用 しているという共通点もあったが，市街地をよく利用し ていた点が異なっていた。尾上ら ${ }^{15)}$ は，秋季は早朝に 住宅地にある墓地や, 寺社の集まる場所へ移動し, 秋季 に実を熟すカキ・ヨウシュヤマゴボウを住宅地内で採食 し，墓地で休息するという行動を繰り返していたことを 報告している。秋季には, 市街地にもカラスが利用でき るエサ資源が存在するため, 市街地の利用が増えたと考 えられる。また, 集中利用域の分布から, 調查地北部も よく利用している（図4）。この地域には畜（鶏）舎が

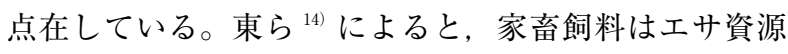
として利用されているので，このような領域をよく利用 したと考えられる。

冬季における集中利用域は夏・秋季よりも広く分布す る傾向が見受けられた（図 5)。また集中利用域内の土 地利用は市街地, 果樹園, 樹林, 草地・牧草地の順に割
合が高かった（図 2)。冬季の集中利用域の分布図から， 集中利用域は夏・秋季よりも広く分布する傾向があるも のの, よく利用していた果樹園は夏・秋季と同様に市街 地と樹林に囲まれた果樹園だった。また秋季同様に, 畜 (鶏) 舎のある調査地北部への帯在が見られた。

\section{3 計画圏域の設定}

本調査地では, 秋・冬季に行動圈が北－南方向もしく は北西 - 南東方向へ広がり, 行動圈がねぐらから最大 $14 \mathrm{~km}$ 離れた場所にまで広がっていた（表 1 , 図 1)。こ れは, ねぐらの南側にある果樹園や調査地北部にある畜 （鷄）舎を餌場として利用しているためであると考えら れる。つまり, 盛岡市内にねぐらを持つカラスは, 盛岡 市内で採餌できなくとも, 近隣市町で採餌することを意 味している。このような状況では, 仮に盛岡市内で適切 なカラス対策を行なったとしても, 盛岡市内にねぐらを 持つカラスは近隣市町でエサ資源を獲得できるため, 同 市内のカラスの個体数の減少を期待することができず, 被害の低減を見込めない可能性がある。そのため, カラ ス対策を講じる計画圈域は, 近隣市町を含む広範囲に設 定する必要がある。他方, 集中利用域内の土地利用より, 各時季で果樹園や樹林をよく利用していた（図 2)。つ まり，カラスは樹木の多い環境をよく利用していたと考 えられる。しかし, 各季節の集中利用域の分布を見ると

(図 3，4，5)，森林内部には集中利用域があまりない ことから,このような環境は除外してよいと考えられる。

以上の条件を本調査地にあてはめると, 盛岡市, 滝沢 市, 矢巾町, 紫波町, 需石町を含む範囲で同じ方針のも と対策を行う必要があると考えられる。つまり, カラス の個体数調整のための「カラスに食べさせない環境づく り」は, 各自治体が独立して行っても効果を期待するこ とはできず，大規模ねぐらを抱える自治体を中心として 近隣の自治体と密に連携して行う必要があると考えられ る。

\section{V まとめ}

これまでに行なわれてきたカラスによる被害への対策 は，有害鳥捕獲罠に頼った個体数削減，もしくは，カラ スを物理的に近づけさせないという，起きた被害に対す る対応だけであった。そのため, ある場所の被害を食い 止めても, カラスが他の場所へ移動してしまい, 広域で の被害の食い止めができなかった。また, 個体数調整を 行なってはいるが, 削減目標数の設定の根拠が不明瞭で あり，実質的な効果を上げていない。本研究では，カラ スの生態に基づいて, 具体的に計画圈域をどのように設 
定するか, カラスが選択的に利用している環境とは具体 的にどのような環境かを示した。カラス被害低減のため には,これまで行われてきた被害に対する迅速な対応と， カラスの行動圈の特徴や選択的に利用している環境の特 徵，何を採慨しているかなどの生態学的な知見に基づく 中・長期的な管理計画に基づく対応の 2 つを同時に進め ていく必要があると考えられる。

また本研究によって, カラスは人の生活の場と隣接す る樹木の多い環境を選択的に利用していたことが明らか になった。人の生活の場と隣接する樹木の多い環境とは, 樹林や果樹園, 緑の多い住宅地などが近接する環境であ る。カラスの生息状況を示すための適切な空間スケール を設定したうえで, 空間スケール内の土地利用のパター ンや各土地利用の面積などの環境情報とカラスの生息状 況との関係を明らかにすることで, 景観構造とカラスの 生息状況との間に関係性があることを示唆する結果が得 られたと考えられる。また，これを解明することができ れば，地域の景観構造からカラスの生息予測ができるの ではないかと考えられる。さらに生息状況と被害との関 係を明らかにすることで, 景観構造の特徵からカラスに よる被害予測を行うことができるのではないかと考えら れる。

\section{謝辞}

本研究は, 盛岡市環境企画課, 東北電力株式会社盛岡営業所 配電技術サービス課, 盛岡猟友会, 岩手大学農学部の学生諸氏 にご協力いただいた。また岩手大学農学部の時田賢一氏には, GPS-TX の装着について, さらにカラス追跡調査の際, どのよ うな点に留意して観察すべきかなど, 調査全般にわたりご指 導いただいた。また, 明治大学農学部登尾浩助先生および Iain McTaggart 先生には英文を校正していただいた。媣く感謝申 し上げます。

\section{引用文献}

$1 ）$ 犬飼哲夫・芳賀良一（1953）：北海道に於けるカラスの被 害と防除の研究：（III）特にカラスの食性と農業との関係, 北大農学部紀要, 1 (4), 459-482.

2 ) 農林水産省（2008）：(参照 2014.4.17）野生鳥獣被害防止マ ニュアル一鳥類編一（オンライン）入手先〈http://www. maff.go.jp/j/seisan/tyozyu/higai/h_manual/h20_03a/index. html $\rangle$

3 ）松田道生（2000）：カラス，なぜ襲う 都市に棲む野生, 河出書房新社, 東京, 119-124.

4) 日本野鳥の会 (2001)：自治体担当者のためのカラス対策 マニュアル，環境省自然環境局.

5 ）百瀬浩・吉田保志子・山口恭弘（2006）：ハシボソガラス とハシブトガラスの営巣密度推定のための予測モデル構築, ランドスケープ研究, 69 (5), 523-528.

6 ）玉田克巳・深松登（1992）：捕獲小屋で捕獲されたハシボ ソガラスとハシブトガラスの捕獲数と齢構成の季節変化, 日 本鳥学会誌, 40, 79-82.

7 ) 吉田保志子 (2006)：カラスの生態と被害対策について, 農業技術，61（10）, 13-17.

8 ）井上雅央 (2008)：イノシシ シカ サル これならでき る獣害対策, 農山漁村文化協会, 東京, 12-20.

9 ）東淳樹（2014）: 盛岡市広域圈におけるカラスによる被害 とその対策一あなたは被害者？それとも加害者？カラスの との共生の道を探る一, 2014 カラスシンポジウム講演要旨, $4-5$

10）玉田克巳（2004）：北海道池田町におけるハシボソガラス とハシブトガラスの外部計測值とその性差, 日本鳥学会誌, $53(2), 93-97$.

11）矢澤正人 · 時田賢一 - 高橋広和 - 東淳樹 - 前嶋美紀 - 瀬川 典久·玉置晴朗 (2012)：鳥類に装着する GPS-TX の測位精 度の評価, 日本鳥学会 2012 年度大会講演要旨集, 159 .

12）尾崎研一 - 工藤环磨 (2002)：哺乳類の行動圈研究の現状 と将来及びテレメトリー法デー夕行動圈解析法 行動圈 : そ の推定法, 及び観察点間の自己相関の影響, 日本生態学会誌, 52, 233-242.

13）藤田紀之・東淳樹・服部俊宏（2013）：盛岡市における八 シブトガラス・ハシボソガラスの生息分布と土地利用に対す る選好性，農業農村工学会論文集，287，19-26.

14）東淳樹・瀬川典久・高橋広和・西千秋・時田賢一・矢澤正 人・玉置晴朗 (2012)：GPS-TXを用いたハシブトガラスの 行動追跡, 日本鳥学会 2012 年度大会講演要旨集, 162 .

15）尾上舞・藤田紀之・東淳樹 ·瀬川典久·矢澤正人・後閑政昭· 前嶋美紀・時田賢一・高橋広和 (2013) : ハシブトガラスの 一日 一カラスの行動とその経時変化一, 日本鳥学会 2013 年度大会講演要旨集, 178 .

Summary: For developing a policy to control a crow population, we determined a planning area based on the characteristics of the Minimum convex polygon (MCP) method. The calculated MCP home-range size indicates that control policy measures should be conducted in conjunction with neighboring municipalities. We also used the fixed kernel method to estimate crow's core area, and then determined the land-use characteristics of this area. Crows used Lefy residential area, forest, fruits farm in Summer, they used fruits farm, urban area, forest in Autumn, and they used urban area, fuits farm, forest, grass farm in winter.

キーワード (Keywords) : ハシブトガラス (Jungle crow), 行動圈 (Homerange), 計画圈域 (Planning area), 個体数調整対策 (Policy to control Jungle crow population) 